A Preliminary Evaluation of Bank Storage Associated with Libby Reservoir in

Northwestern Montana

GEOLOGICAL SURVEY WATER-SUPPLY PAPER 1899-L

Prepared in cooperation with the Montana Bureau of Mines and Geology, Butte, Montana 


\section{A Preliminary Evaluation of}

\section{Bank Storage Associated with}

\section{Libby Reservoir in}

Northwestern Montana

By DONALD L. COFFIN

CONTRIBUTIONS TO THE HYDROLOGY OF THE UNITED STATES

GEOLOGICAL SURVEY WATER-SUPPLY PAPER $1899-\mathrm{L}$

Prepared in cooperation with the

Montana Bureau of Mines and Geology, Butte, Montana

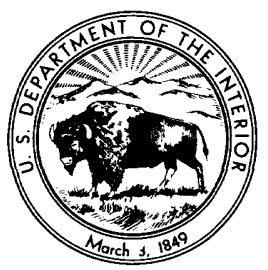




\section{UNITED STATES DEPARTMENT OF THE INTERIOR}

WALTER J. HICKEL, Secretary

\section{GEOLOGICAL SURVEY}

William T. Pecora, Director

Library of Congress catalog-card No. 73-608591

For sale by the Superintendent of Documents, U.S. Government Printing Office Washington, D.C. 20402-Price 25 cents (paper cover) 


\section{CONTENTS}

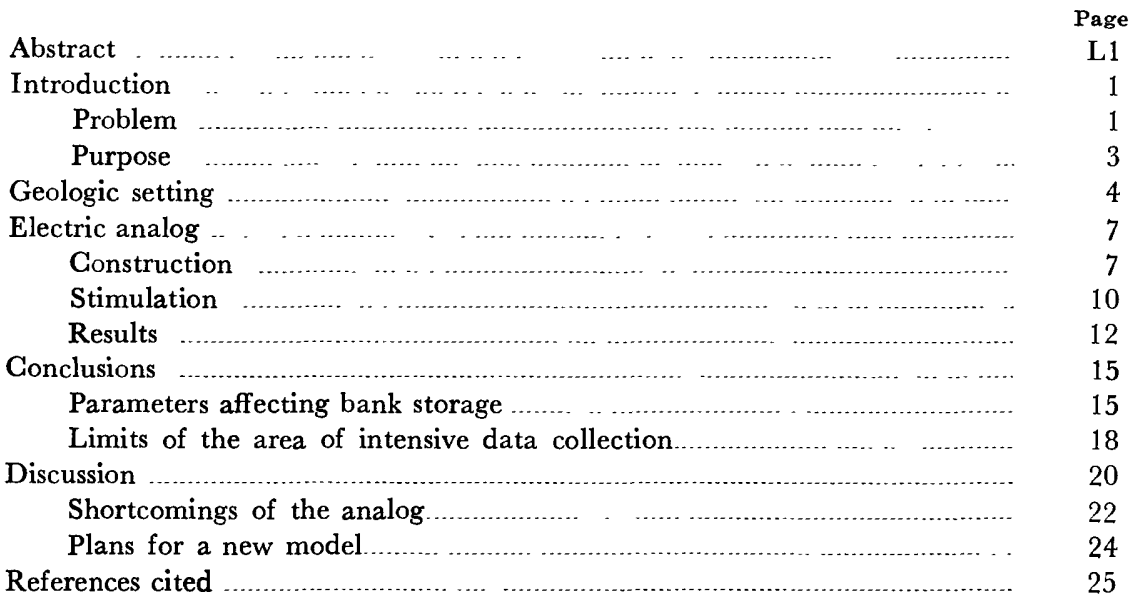

\section{ILLUSTRATIONS}

FIGURE 1. Index map of northwestern Montana and Eastern British Columbia

Page

2. Surficial geologic map of Tobacco Plains area in northwestern Montana

3. Sketches comparing a diagrammatic geologic section with the conditions assumed in the electric analog and in the mathematical model of Cooper and Rorabaugh

4. Schematic sketch of the Kootenai River profile and the annual pulse applied to subdivisions of the reservoir

5. Photographs of the oscilloscope face showing cumulative bank storage and water-level changes

6. Graph showing cumulative bank storage for analog runs 1, 2, and 3

7. Graph showing cumulative active bank storage above Rexford

\section{TABLES}

TABLE 1. Hydraulic characteristics assumed for the geologic units

2. Active bank storage along Libby Reservoir

3. Summary of water-level fluctuations in various lithologic types and at various distances from the reservoir 


\title{
A PRELIMINARY EVALUATION OF BANK STORAGE ASSOCIATED WITH LIBBY RESERVOIR IN NORTHWESTERN MONTANA
}

\author{
By Donald L. Coffin
}

\begin{abstract}
Permeable sand and gravel deposits beneath the floor of the Rocky Mountain Trench in northwestern Montana and southeastern British Columbia will become saturated and provide additional storage for Libby Reservoir, which is scheduled to begin filling in 1972. Because subsurface geologic data are insufficient to predict accurately the amount of usable bank storage, plans cannot be made to use this water for project purposes. An electric analog of the area is too crude to make final estimates of bank storage, but the model study points out that the distribution of active bank storage along the reservoir is mainly a function of the size and shape of the reservoir stage hydrograph and of the slope of the floor of the reservoir. The magnitude of active bank storage is controlled by transmissivity and storage coefficient. The model study indicates that geologic data necessary to evaluate bank storage accurately need only be collected over about one-fourth of the length of the reservoir and within about 2 miles of its edge. The study allowed the estimated cost of the data collection plan to be reduced by about half.
\end{abstract}

\section{INTRODUCTION}

PROBLEM

The U.S. Army Corps of Engineers is building Libby Dam on the Kootenai River in northwestern Montana (fig. 1). The length of the reservoir will be about 90 miles, of which about 40 miles will be in Canada. About 50 miles of the reservoir will be in the Rocky Mountain Trench, which contains unconsolidated deposits of sand and gravel. Bank storage may be important in the operation of the reservoir because the sand and gravel deposits are permeable and be- 


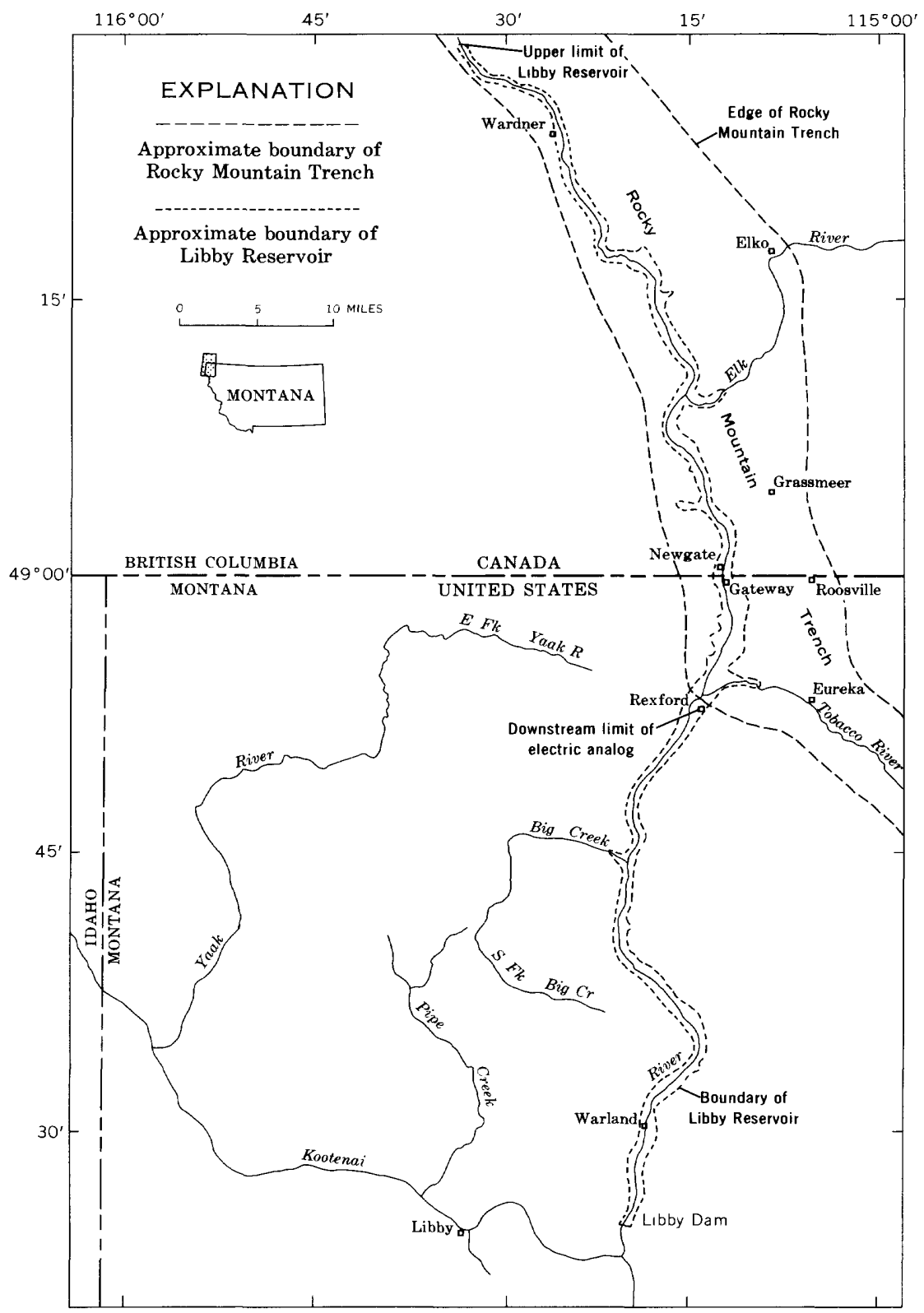

Base map from U.S. Corps of Engıneers

FIGURE 1.-Index map of northwestern Montana and southeastern British Columbia.

cause the yearly change in stage of the reservoir can be as much as 172 feet under critical water conditions. 
Bank storage is water absorbed into aquifers adjoining a reservoir when the stage of the reservoir rises above the water table in the aquifers. Some of the water may return to the reservoir when the reservoir stage falls below the water table in the aquifers. In some reservoirs, the amount of bank storage may be large enough to increase significantly the amount of water available from the reservoir. Capacity tables for most reservoirs do not include bank storage. An accurate determination of bank storage will allow more efficient operation of the reservoir for its various beneficial uses. For reservoirs used primarily for generating electricity, an accurate capacity table including usable bank storage allows optimum generation of firm power, which commands the highest price.

The water resources of the Kootenai valley above Libby dam have been little developed, mainly because of sparse population and abundant water. As a result, very few hydrogeologic data are available, especially those data defining the ground-water system. Much of the area is heavily timbered and relatively inaccessible, especially during the winter; thus, data necessary to evaluate bank storage are difficult and expensive to collect. The aim of a study by the U.S. Geological Survey and the Montana Bureau of Mines and Geology was to estimate bank storage. Sufficient data were not available for an accurate estimate and funds are not currently available for an extensive data-collection program. Therefore, it seemed advisable to make a preliminary evaluation with a view toward defining the most important data to collect for a more accurate estimate. This preliminary evaluation also developed guidelines that could be used to relate the cost of collecting data to the benefits that would accrue from its use.

\section{PURPOSE}

This paper describes how a simple electric-analog model was used as an aid in designing a data-collection program. The analog was developed to help the hydrologist relate various physical parameters of the system to bank storage and to evaluate the relative importance of the parameters. A data-collection program can then be designed to measure these parameters in the areas where they most affect bank storage. A data-collection program developed from the relationships made clear by the model will result in a controlled collection of data and should minimize the collection of data that have little use in the final analysis. In addition to the above, the range of bank storage was estimated. This estimate is much too crude for use in managing the reservoir; however, it does 


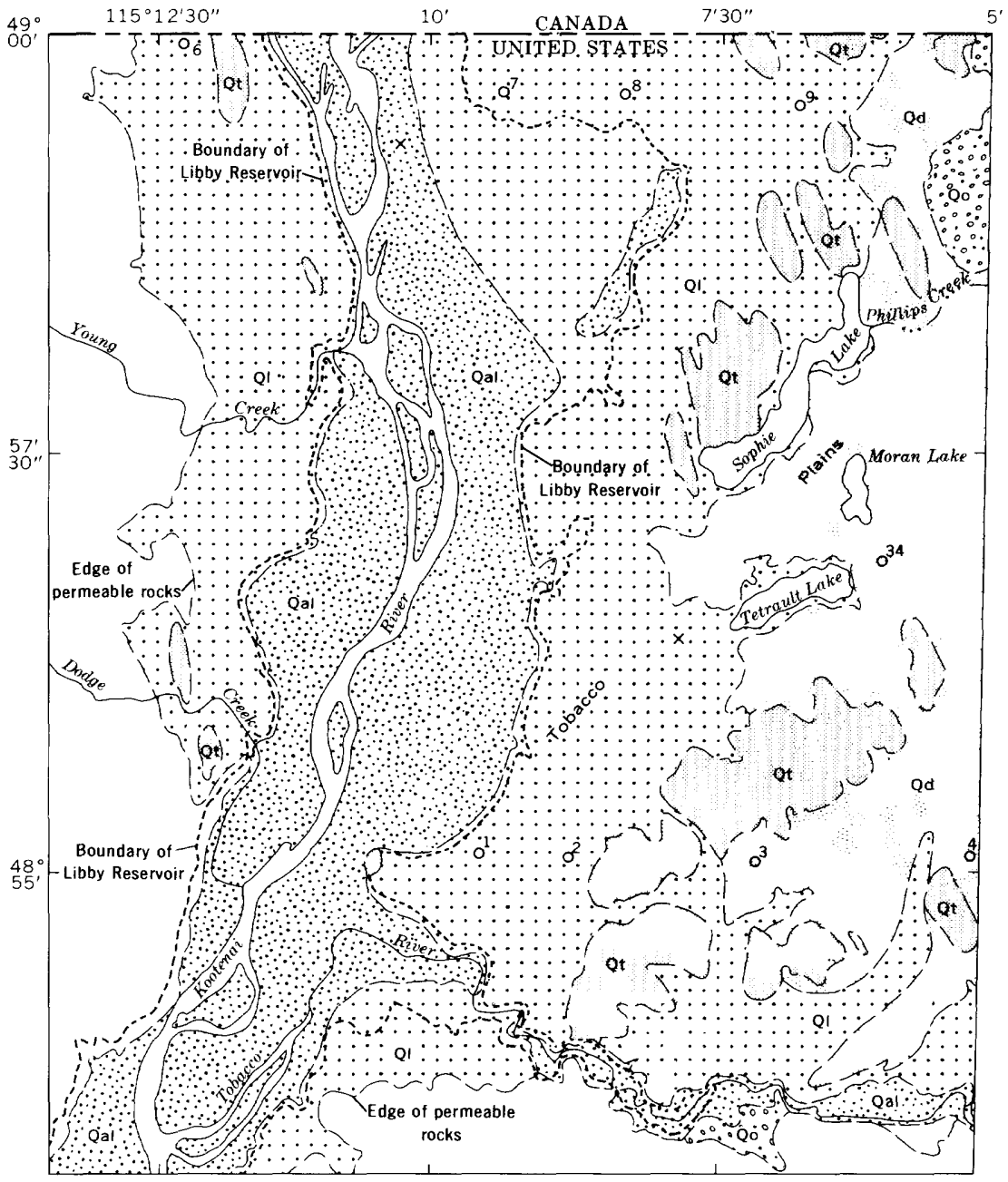

Base from U.S. Geological Survey

Rexford and Eureka North $1: 24000,1963$

Figure 2.-Surficial geologic map of Tobacco

provide an order of magnitude of the amount of bank storage that might be available.

\section{GEOLOGIC SETTING}

The Kootenai River flows southward down the broad valley of the Rocky Mountain Trench into the United States and leaves the trench about 10 miles south of the international boundary (fig. 1). In the United States the trench seems to be a graben 

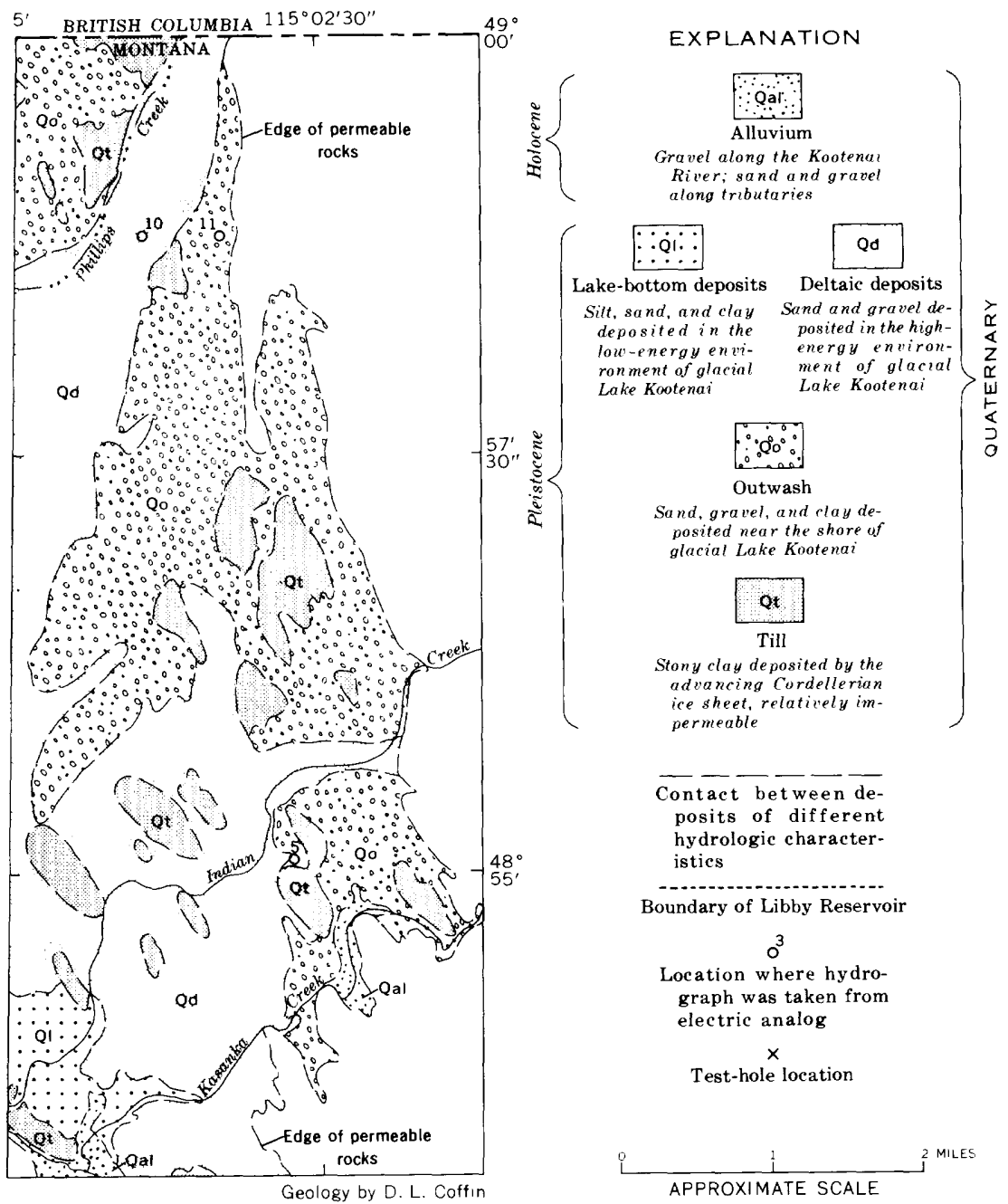
permeable

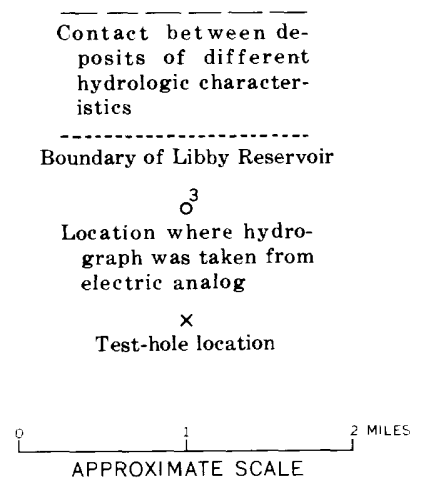

Plains a. ea in northwestern Montana.

having a floor about 7 miles wide and a vertical displacement of several thousand feet. The walls are Precambrian sedimentary and low-grade metamorphic rocks. Since its formation during Tertiary time, the trench has been partly filled by debris from the adjacent mountains. Most of the debris forming the floor of the trench is Pleistocene and Holocene deposits of unconsolidated silt, sand, and gravel. The Kootenai River has cut a valley as much as a mile wide and 200-300 feet below the floor of the trench. 
Little evidence of geologic history prior to Pleistocene time can be seen from rocks exposed on the floor of the Rocky Mountain Trench. The last glacial advance filled the trench with more than 5,000 feet of ice and modified the rocks so greatly that evidence of earlier events was almost completely removed or deeply buried. As the ice moved down the trench, it ground and compacted the underlying deposits into clay till. Till was mounded into drumlinlike hills on the floor of the trench and was plastered over the Precambrian rock walls. Eventually the ice began to melt and the front receded to the north. The ancestral Kootenai river became dammed by ice or by isostatic rebound downstream from the trench, whereupon the floor of the trench became covered by as much as 400 feet of water. Streams from the adjacent mountains deposited their loads along the foot of the steep walls of the trench. In most places this area of deposition was near or along the shore of the lake. These outwash deposits range in size from sand to boulders and contain less than 20 percent of clay.

The streams reworked the outwash and carried much of the material into the lake, where it was further reworked and resorted by lake currents. Coarser material formed deltas radiating from the mouths of tributaries. The deltaic deposits, which grade into and interfinger with the outwash, are well sorted and range from coarse sand to medium gravel. Interfingering lakeward with the deltaic deposits are the lake-bottom deposits of silt, clay, and fine to medium sand. The lake-bottom deposits resulted from the settling of sediment from the turbid lake water. Deposits associated with the glacial lake rest on till. Many of the drumlinlike hills of till were not completely covered by lake deposits and now form streamlined mounds projecting above the relatively level lake-floor surface.

After recession of glacial conditions, the glacial lake drained and the Kootenai River entrenched itself 200 to 300 feet into the lakebottom deposits. This inner valley is generally less than a mile wide, and its floor is underlain by about 50 feet of medium to very coarse gravel. The inner valley will contain the reservoir formed by Libby Dam (fig. 1).

A reconnaissance geologic map was made of the surficial deposits on the floor of the Rocky Mountain Trench between Rexford and the upper limit of the reservoir. The areal distribution of the geologic units in the United States part of the trench is shown in figure 2. However, few subsurface data are available, and the thickness or configuration of the base of the surficial deposits cannot be mapped. Two test 
holes were drilled in the Tobacco Plains during the studyone through the alluvium along the Kootenai River and the other in the area where the deltaic deposits and lake-bottom deposits interfinger. The test holes confirmed the interpretation of the geology. The first test hole shows 44 feet of alluvium lying on lake-bottom sand and silt. The second shows 158 feet of deltaic deposits interfingering with lake-bottom deposits and resting on till.

\section{ELECTRIC ANALOG}

\section{CONSTRUCTION}

In order to construct an analog model of the reservoir and adjacent aquifers, the subsurface distribution of the geologic units was assumed to be the same as the surface configuration, and values of $T$ (transmissivity) and $S$ (storage coefficient) were assumed for each geologic unit. The assumed values are based on the lithologic characteristics of the rocks penetrated by the test holes and on known values for similar rock types in nearby areas. The values assumed for the three model runs are given in table 1 . These as-

$\mathrm{T}_{\mathrm{ABLE}}$ 1.-Hydraulic characteristics assumed for the geologic units

\begin{tabular}{|c|c|c|c|c|c|}
\hline \multirow{2}{*}{$\begin{array}{c}\text { Geologic } \\
\text { unit }\end{array}$} & \multirow[b]{2}{*}{ Lithology } & \multirow{2}{*}{$\underset{\left(\mathrm{ft}^{2} \text { day }^{-1}\right)}{\text { Transmity }}$} & \multicolumn{3}{|c|}{ Coefficient of storage } \\
\hline & & & Run 1 & Run 2 & Run 3 \\
\hline Alluvium & Gravel ...... & 67,000 & 0.20 & 0.10 & 0.40 \\
\hline $\begin{array}{l}\text { Lake-bottom } \\
\text { deposits. }\end{array}$ & Silt, clay, sand & 1,300 & .05 & .025 & .10 \\
\hline Deltaic deposits & Sand, gravel & 13,000 & .15 & .075 & .30 \\
\hline Outwash & Sand, gravel, clay & 9,300 & .10 & .05 & .20 \\
\hline & Clay, sand, boulders & 0 & & & \\
\hline $\begin{array}{l}\text { Precambrian } \\
\text { strata. }\end{array}$ & $\begin{array}{l}\text { Dolomite, argillite, } \\
\text { quartzite }\end{array}$ & 0 & & . & \\
\hline
\end{tabular}

sumptions essentially convert the three-dimensional mental image develosed by the geologist into a two-dimensional simple hydrologic model. The three-dimensional image can, for lack of a better word, be called a conceptual model. A diagrammatic cross section of the conceptual model is shown in figure 3. Included for comparison in figure 3 is a schematic sketch of the analog and of the analytic model developed by Cooper and Rorabaugh (1963). The relation of the geology to the hydraulic characteristics of the groundwater system can be visualized by viewing each geologic unit shown in figures 2 and 3 as an area of uniform ability to store and transmit water. Discussion of the assumptions and the validity of the conceptual model is reserved for later in the paper. 


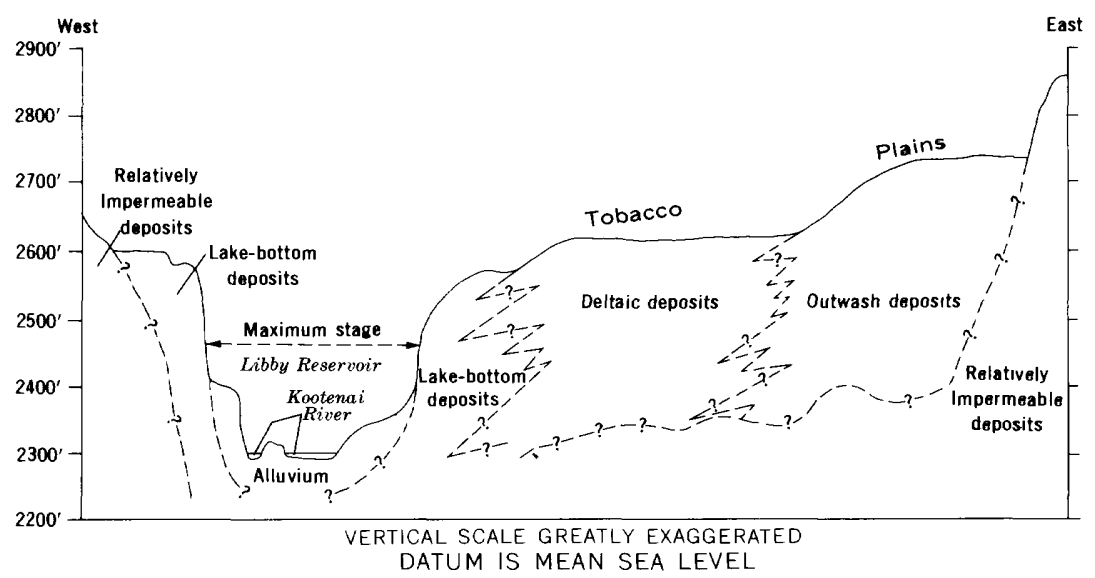

Diag, ...- matic geologir, section across the Tobacco Plains

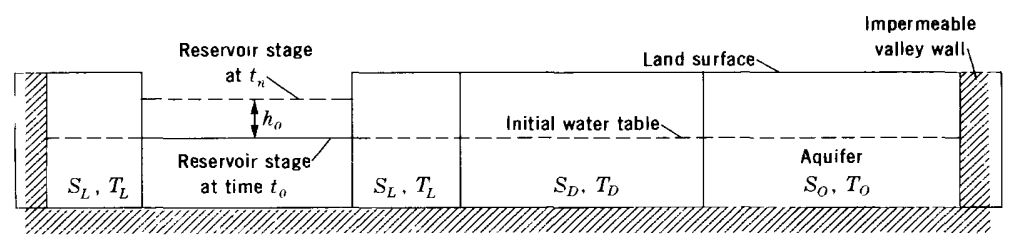

Sketch of aquifer across the Tobacco Plains as assumed for the electric analog

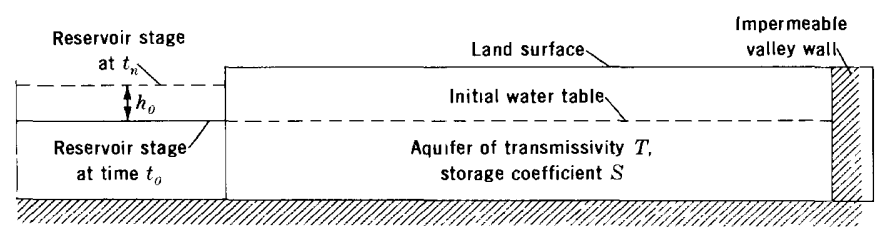

Sketch of aquifer across the Tobacco Plains as assumed for the mathematical model of Cooper and Rorabaugh (1963)

Figure 3.-Sketches comparing a diagrammatic geologic section with the conditions assumed in the electric analog and in the mathematical model of Cooper and Rorabaugh (1963). $S_{L}, S_{D}$, and $S_{O}$ are the storage capacities of the lake-bottom, deltaic, and outwash deposits, respectively; $T_{L}, T_{D}$, and $T_{O}$ are the transmissivities of these deposits. The initial time is $t_{0}$; some later time is $t_{n}$. The difference between the reservoir stages at these times is $h_{0}$.

The area modeled is the floor of the Rocky Mountain Trench from 5 miles north of the head of the reservoir southward to Rex- 
ford. The model includes the part of the reservoir between the maximum and minimum stages.

A network of resistors and capacitors was built at a scale of 1 inch equals $1 / 2$ mile. The shape and size of the aquifer boundaries is the same as those of the geologic units mapped in the field. Each unit's ability to store and transmit water is represented by an appropriate value of capacitance and resistance. The reservoir area, which is represented by a low-resistance wire connected directly to the aquifer network and to ground, is divided into subareas connected to each other by a diode. Subareas were determined by the depth of water at maximum stage of the reservoir. Each subarea represents an area of the reservoir where the valley floor slopes 10 feet.

Description of the model is summarized by the following list of assumptions:

1. Flow in the aquifer is two dimensional.

2. Bank storage is a linear function of reservoir stage and time.

3 . The reservoir is in full hydraulic connection with the adjacent aquifer.

4. The reservoir fully penetrates the aquifer and has vertical banks.
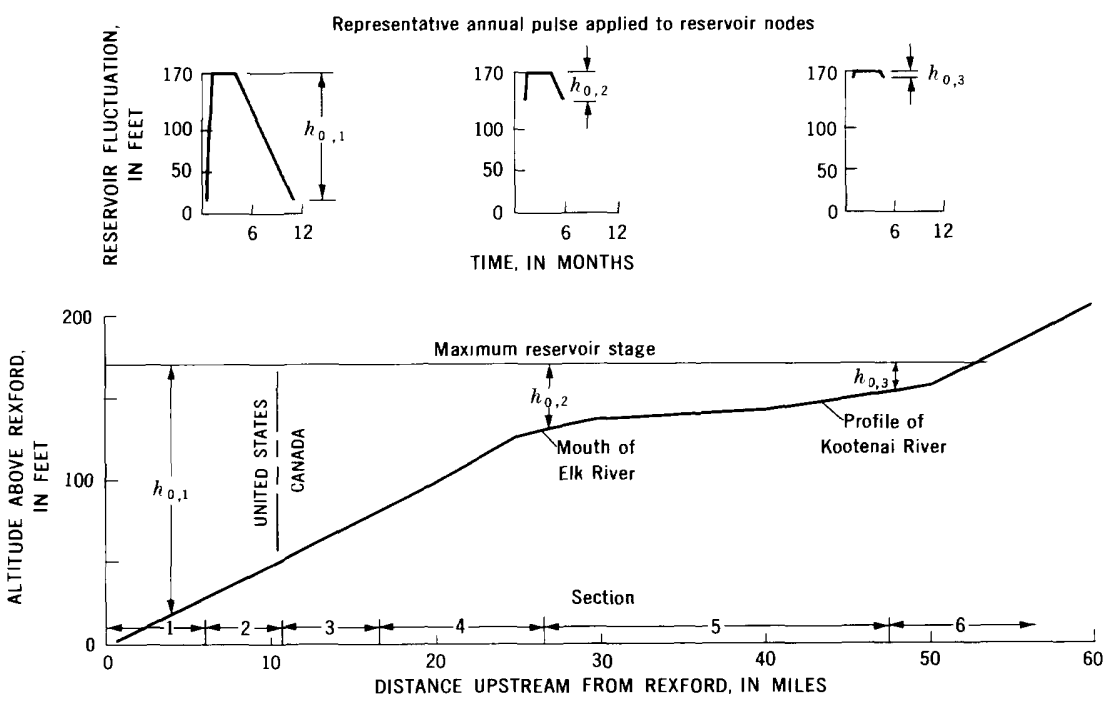

FIGURE 4.-Schematic sketch of Kootenai River profile and the annual pulse applied to subdivisions of the reservoir. The sections represent areas of the reservoir where bank storage was measured on the analog. The maximum rise of reservoir stage, in feet, is $h_{0}$. 

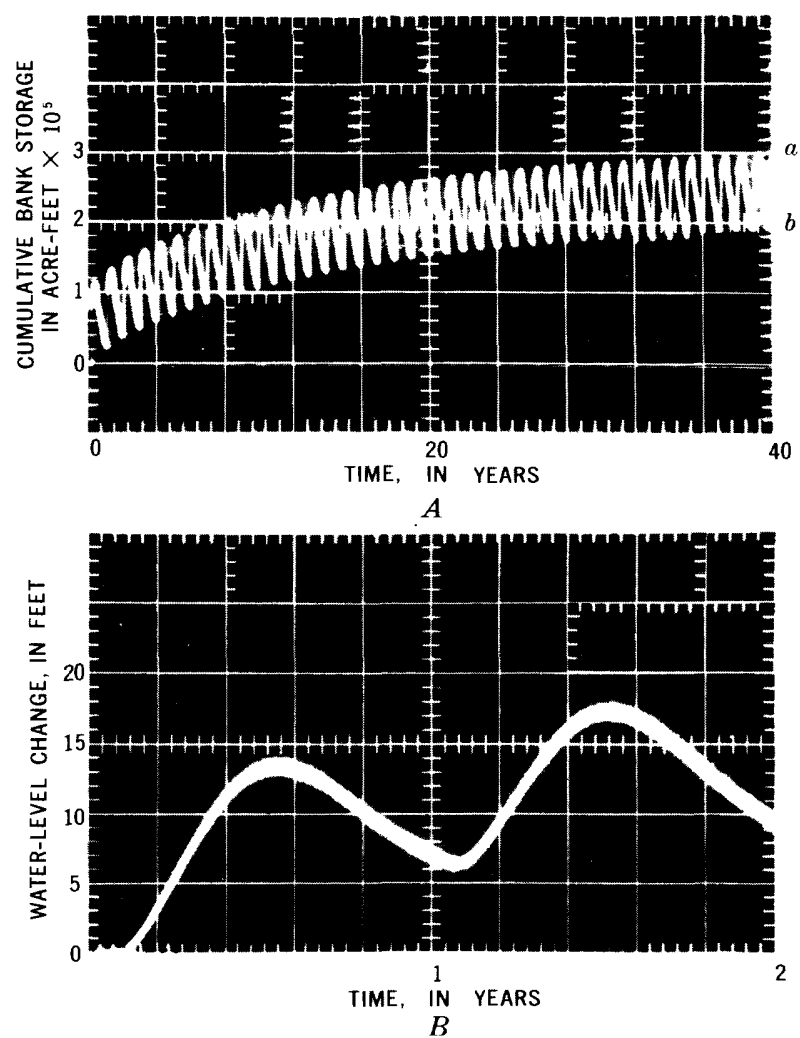

FIGURE 5.--Photographs of the oscilloscope face showing cumulative bank storage and water-level changes. $A$, Total volume of cumulative bank storage at any instant; the cyclic changes between $a$ and $b$ represent the yearly change in cumulative bank-storage volume; run 2. $B$, Water-level changes at an expanded time scale and at a location 2 miles east of the reservoir; run 1 , hydrograph at location 34 . $C$, Water-level changes for 40 years at the same location as $B$; run 2 , hydrograph at location 34. $D$, Water-level changes at a location half a mile from the reservoir; run 2, hydrograph at location 2.

5. The initial potentiometric surface is in equilibrium and the only cause of fluctuation is the reservoir.

6. The subsurface distribution of the geologic units is the same as the surface configuration and each geologic unit has a uniform ability to store and transmit water.

\section{STIMULATION}

The model is stimulated by applying to it an electric pulse that represents the annual fluctuation in stage proposed for the reser- 

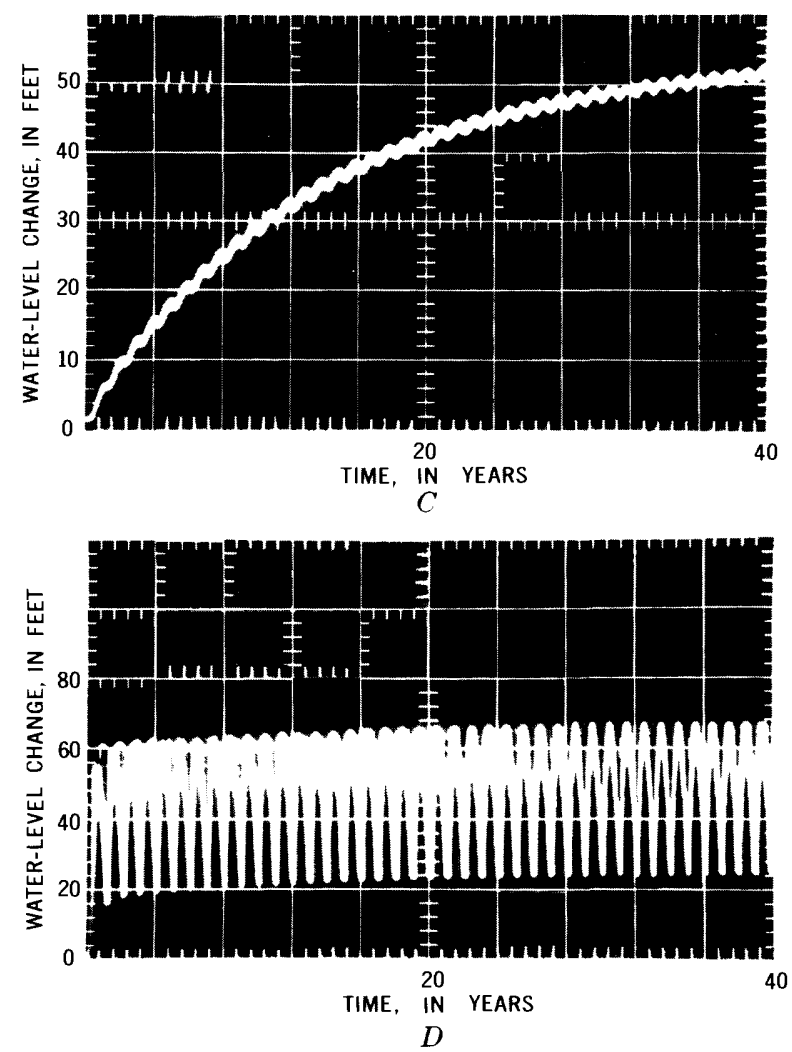

voir (fig. 4). Stimulation is the process of exciting the passive elements of the model to simulate the operation of the reservoiraquifer system. Each subarea is stimulated by a pulse of different magnitude at a slightly different time (fig. 4) to account for the reservoir's variance of depth and fluctuation in space as well as time. The pulse from the wave generator is divided by a diode network so that each upstream subarea receives a smaller pulse than the adjacent downstream subarea (fig. 4).

The model was stimulated by applying to it a pulse representing 40 years of equal stage fluctuations. Current from the reservoir (rate) was integrated with time to measure the volume of bank storage (fig. $5 A$ ). To find the areal distribution of bank storage, current was measured from sections of the reservoir (fig. 4). Each section consisted of four or more subareas. Each subarea, in turn, represented a reach of the Kootenai River profile having a difference of 10 feet in elevation.

Though not a direct measure of bank storage, water-level (voltage) changes were measured at 34 random points throughout the floor of the Rocky Mountain Trench. These measurements show 
the effect of the reservoir at various places in the aquifer. Oscilloscope hydrographs of two points are shown in figure 5 ; their locations are shown in figure 2.

Bank storage and water-level changes were measured at the same locations during three model runs. The coefficient of storage was changed proportionally everywhere on the model before the second and third runs. During the second run, $S$ was one-half of initial $S$; and during the third run, $S$ was twice initial $S$. Because the volume of bank storage depends upon the product of $S$ and $T$ and upon the ratio of $T$ to $S$, varying the magnitude of $S$ causes the model to represent bank storage for a set of different aquifer parameters, which are $T S$ and $T / S$ (See section on "Parameters affecting bank storage.")

\section{RESULTS}

The model analysis helps to understand how the fluctuating reservoir stage could affect the aquifer. Figure $5 B$ shows an oscilloscope picture at an expanded scale of a well hydrograph about 2 miles east of the reservoir. The yearly stage fluctuation of the reservoir ( $160 \mathrm{ft}$ on the reservoir directly west of the well) has been damped to about 12 feet and delayed by about 40 days. At the end of the first reservoir cycle, not all the water has drained that entered the aquifer during the rising reservoir stage. Thus, after each cycle, more water is in the aquifer than before the cycle. Theoretically, given enough time and equal cycles of the reservoir, the fluctuation would approach simple harmonic motion and cause the water-level fluctuation in the aquifer to be damped harmonic motion. When the reservoir-aquifer system reaches this condition, it has achieved a periodic steady state, and equal amounts of water are gained and lost each year. Under these conditions, in a semiinfinite aquifer fully penetrated by a reservoir with a level floor, the water levels in the aquifer would annually fluctuate about a net rise equal to half the reservoir fluctuation opposite the point (Jacob, 1950, p. 365). Also, the amplitude of the annual waterlevel fluctuations would decrease exponentially with distance from the reservoir. At Libby Reservoir the yearly fluctuation is not everywhere constant because the reservoir floor slopes and the aquifer is not infinite. These two facts would cause the annual water levels to fluctuate about a net rise of less than one-half of the reservoir fluctuation opposite the point in the aquifer. The time for the aquifer to reach the periodic steady state varies from a few years near the reservoir to more than 40 years at places far from the reservoir (fig. $5 C$ and $D$ ). In a semi-infinite aquifer under periodic steady-state conditions, simple calculations using heat- 
flow equations can be made to find the head distribution, volume of bank storage, and time lags (Ferris, 1950). Such calculations illustrate the entire reservoir-aquifers system only after many years of equal reservoir cycles. In the real reservoir-aquifer system unequal annual reservoir cycles might prevent the system from reaching a periodic steady state during the life of the reservoir.

It is convenient, at this point, to simplify the oscilloscope photographs showing the accumulated volume of bank storage (fig. 5A). The distance below a line drawn to connect the points of least annual volume of bank storage represents the minimum volume of bank storage that will go into inactive storage in the aquifer. This water will not return to the reservoir under presumed operating conditions and is called inactive bank storage. If, however, the reservoir did not always fill, the inactive bank storage would be released to the reservoir until all the inactive storage was returned or until the stage of the reservoir rose. The distance above the lower line and below the line connecting the points of highest annual volume of bank storage represents the volume of water that will return to the reservoir each year. This water is called active bank storage. Shortly after the first few cycles of reservoir fluctuation, active bank storage approaches a constant value. Curves showing the total active and inactive bank storage for runs 1,2 , and 3 are shown in figure 6 . The amounts of active bank storage are tabulated for sections (fig. 4) of the reservoir in table 2.

TABLE 2.-Active bank storage along Libby Reservoir

\begin{tabular}{|c|c|c|c|c|c|c|c|}
\hline \multirow[b]{2}{*}{ Section $\begin{array}{c}\text { Distance } \\
\text { upstream } \\
\text { Rrom } \\
\text { (miles) }\end{array}$} & \multicolumn{2}{|c|}{ Run 1} & \multicolumn{2}{|c|}{ Run 2} & \multicolumn{2}{|c|}{ Run 3} & \multirow{2}{*}{$\begin{array}{l}\text { Accumu- } \\
\text { lated } \\
\text { average } \\
\text { percent of } \\
\text { average } \\
\text { active } \\
\text { bank } \\
\text { storage } \\
\text { for all } \\
\text { runs }\end{array}$} \\
\hline & $\begin{array}{l}\text { Average } \\
\text { active } \\
\text { bank } \\
\text { storage } \\
\text { (acre-ft) }\end{array}$ & $\begin{array}{c}\text { Percent } \\
\text { of } \\
\text { total }\end{array}$ & $\begin{array}{l}\text { Average } \\
\text { active } \\
\text { bank } \\
\text { storage } \\
\text { (acre-ft) }\end{array}$ & $\begin{array}{c}\text { Percent } \\
\text { of } \\
\text { total }\end{array}$ & $\begin{array}{l}\text { Average } \\
\text { active } \\
\text { bank } \\
\text { storage } \\
\text { (acre-ft) }\end{array}$ & $\begin{array}{c}\text { Percent } \\
\text { of } \\
\text { total }\end{array}$ & \\
\hline $\begin{array}{rrr}\mathbf{1} & \ldots & \mathbf{5 . 5} \\
\mathbf{2} & \ldots & \mathbf{1 0 . 0} \\
\mathbf{3} & \ldots & \mathbf{1 6 . 0} \\
\mathbf{4} & \ldots & \mathbf{2 6 . 2} \\
\mathbf{5} & \ldots & \mathbf{4 5 . 2} \\
\mathbf{6} & -\ldots & \mathbf{5 1 . 2}\end{array}$ & $\begin{array}{l}95,000 \\
44,000 \\
27,000 \\
26,000 \\
16,000 \\
16,000\end{array}$ & $\begin{array}{r}42 \\
20 \\
12 \\
12 \\
7 \\
7\end{array}$ & $\begin{array}{r}48,000 \\
19,000 \\
14,000 \\
12,000 \\
9,000 \\
8,000\end{array}$ & $\begin{array}{r}44 \\
17 \\
13 \\
11 \\
8 \\
7\end{array}$ & $\begin{array}{r}176,000 \\
64,000 \\
34,000 \\
34,000 \\
28,000 \\
24,000\end{array}$ & $\begin{array}{r}49 \\
18 \\
9 \\
9 \\
8 \\
7\end{array}$ & $\begin{array}{r}45 \\
63 \\
74 \\
85 \\
93 \\
100\end{array}$ \\
\hline Total & 224,000 & 100 & 110,000 & 100 & 360,000 & 100 & ......... \\
\hline
\end{tabular}

Note.-Active bank storage, in acre-ft, in the alluvium along the Kootenai River as estimated by the U.S. Corps of Engineers as follows:

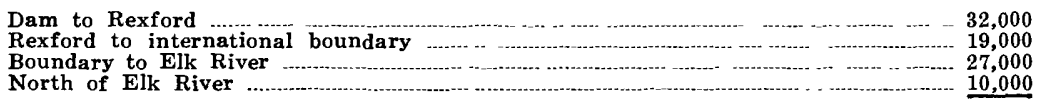

Total

88,000 


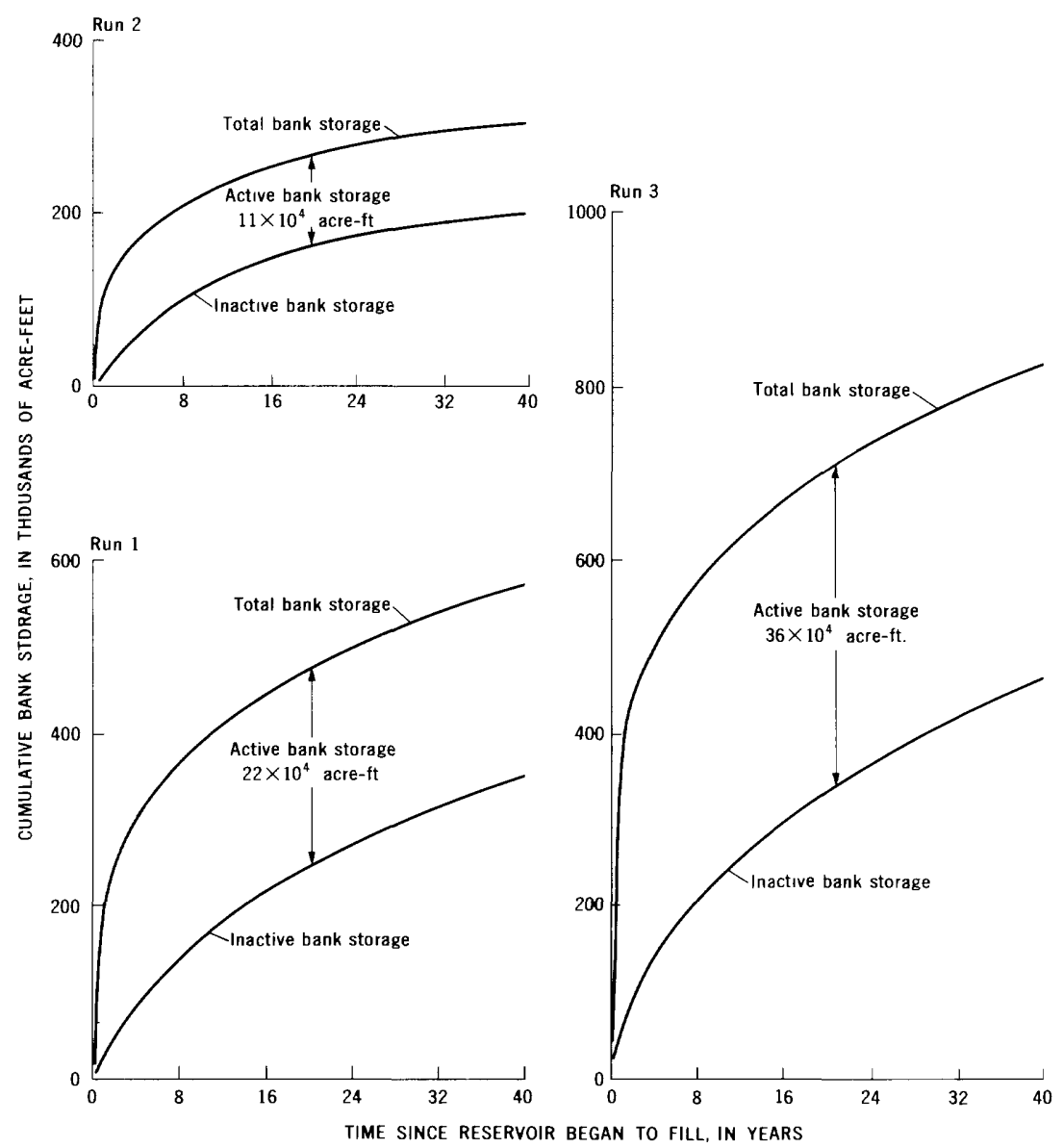

FigURE 6.-Cumulative bank storage for analog runs 1, 2 and 3. Aquifer characteristics for each run are shown in table 1 .

Because the analog assumes a completely penetrating reservoir, the estimates of active bank storage do not include storage in the Kootenai River alluvium that is exposed at low stage of the reservoir but is covered by water at high stage of the reservoir. The U.S. Army Corps of Engineers has estimated the volume of alluvium along the Kootenai valley and the active bank storage in this alluvium as part of an independent and unpublished study (table 2). This part of the estimate by the Corps assumes a "water exchange" of 2 to 12 percent based on the lithology and permeability of the deposits. The estimate includes a relatively small volume of alluvium that will not be covered at high stage of the reser- 
voir, but the estimate by the Corps can be used to help evaluate the amount of active bank storage not included in the analog.

Water-level fluctuations measured at various nodes in the aquifer model provide a comparative index that relates the amount of bank storage to the various lithologic rock types at various distances from the reservoir. A summary of the average yearly waterlevel fluctuations of 34 random nodes is shown in table 3 . It is difficult to generalize from table 3 because each node point is

TABLE 3.--Summary of water-level fuctuations in various lithologic types and at various distances from the reservoir

\begin{tabular}{|c|c|c|c|c|}
\hline \multirow[b]{2}{*}{ Average lithologic type } & \multirow[b]{2}{*}{$\begin{array}{c}\text { Distance from reservoir } \\
\text { (miles) }\end{array}$} & \multicolumn{3}{|c|}{$\begin{array}{c}\text { Average yearly range } \\
\text { in fluctuation } \\
\text { (feet) }\end{array}$} \\
\hline & & Run 1 & Run 2 & Run 3 \\
\hline $\begin{array}{l}\text { Silt and sand } \\
\text { Gravel } \\
\text { Silt and sand } \\
\text { Sand and gravel } \\
\text { Sand, gravel and clay }\end{array}$ & $\begin{array}{r}0.1-0.2 \\
.1-.2 \\
.4-1.0 \\
1.1-1.8 \\
2.1-5.5\end{array}$ & $\begin{array}{r}41 \\
15 \\
20 \\
<10 \\
<10\end{array}$ & $\begin{array}{r}23 \\
8 \\
14 \\
<10 \\
<10\end{array}$ & $\begin{array}{r}56 \\
18 \\
30 \\
<10 \\
<10\end{array}$ \\
\hline
\end{tabular}

affected differently by the shape and distance to impermeable boundaries and because the reservoir fluctuation is different opposite different nodes. Moreover, conclusions drawn from averages of such widely varying data could be misleading. About all that can be ascertained is that, at distances greater than 2 miles from the reservoir, the average yearly fluctuation may be less than 10 feet. The rise over a period of years due to inactive bank storage may be as much as 80 feet.

\section{CONCLUSIONS}

\section{PARAMETERS AFFECTING BANK STORAGE}

A data-collection program that acquires data in the areas where it will do the most good should be designed with a view toward the parameters that affect bank storage. The results of the analog provide the cumulative volume of bank storage but do not give much direct information about the parameters. Mathematical models show the effect of parameters on bank storage, but usually these models cannot account for the complex geometry of the system, so that the results may not be as accurate as the analog. It is desirable, therefore, to use the mathematical model to see the effect of various parameters on bank storage and to use the analog to calculate the volume of bank storage. 
Cooper and Rorabaugh (1963) found the mathematical solution for the volume of bank storage, caused by a single flood-wave stage oscillation, to be of the form

where

$$
V=h_{0} \sqrt{\frac{T S}{\omega}}[f(S, T, \omega, t, l)],
$$

$$
\begin{aligned}
V & =\text { volume of bank storage, } \\
h_{0} & =\text { maximum rise of reservoir } \\
T & =\text { transmissivity, } \\
S & =\text { storage coefficient, } \\
\omega & =\text { frequency of stage oscillation } \\
t & =\text { time, and } \\
l & =\text { distance to ground-water divide. }
\end{aligned}
$$

The term in brackets is a complex function of the ratio $T: S, \omega$, $t$, and $l$.

A plot from the analog of cumulative active bank storage versus distance upstream from Rexford is shown in figure 7 . Changing the storage coefficients between runs causes the magnitude of the curves to vary. The shape of the curves, however, remains generally the same.

The analog shows that the accumulated volume of bank storage increases most rapidly between Rexford and the mouth of the Elk River. Cooper's and Rorabaugh's equation substantiates this, because it shows that the volume of bank storage increases proportionally to the maximum rise of reservoir stage $\left(h_{0}\right)$. The maximum stage fluctuation will be about 170 feet near Rexford and will decrease upstream to 70 feet at the mouth of the Elk River. Active bank storage also decreases upstream because the reservoir contains water for less time at the upper end. Thus, if there are no great changes in $T$ or $S$ along the length of the reservoir, the distribution in space of active bank storage is largely a function of $h_{0}$ and $\omega$.

Considering only the first term of Cooper's and Rorabaugh's equation: if $h_{\mathrm{o}}$ and $\omega$ are constant, the volume of active bank storage will vary as $\sqrt{T S}$. In any cross section of Libby Reservoir the maximum $h_{0}$ is determined by the height of the dam and by the slope of the streambed, and $\omega$ is determined by the operation of the reservoir. If the most efficient operation of the reservoir requires nearly a maximum fluctuation each year and a similar stage hydrograph each year, then the total volume of active bank storage is largely controlled by $T$ and $S$ of the aquifer.

Cooper and Rorabaugh show how the reservoirs stage fluctuation affects both the magnitude and the time distribution of bank storage. Also, the analog shows that the total volume of bank storage at any time depends on antecedent reservoir fluctuations. 


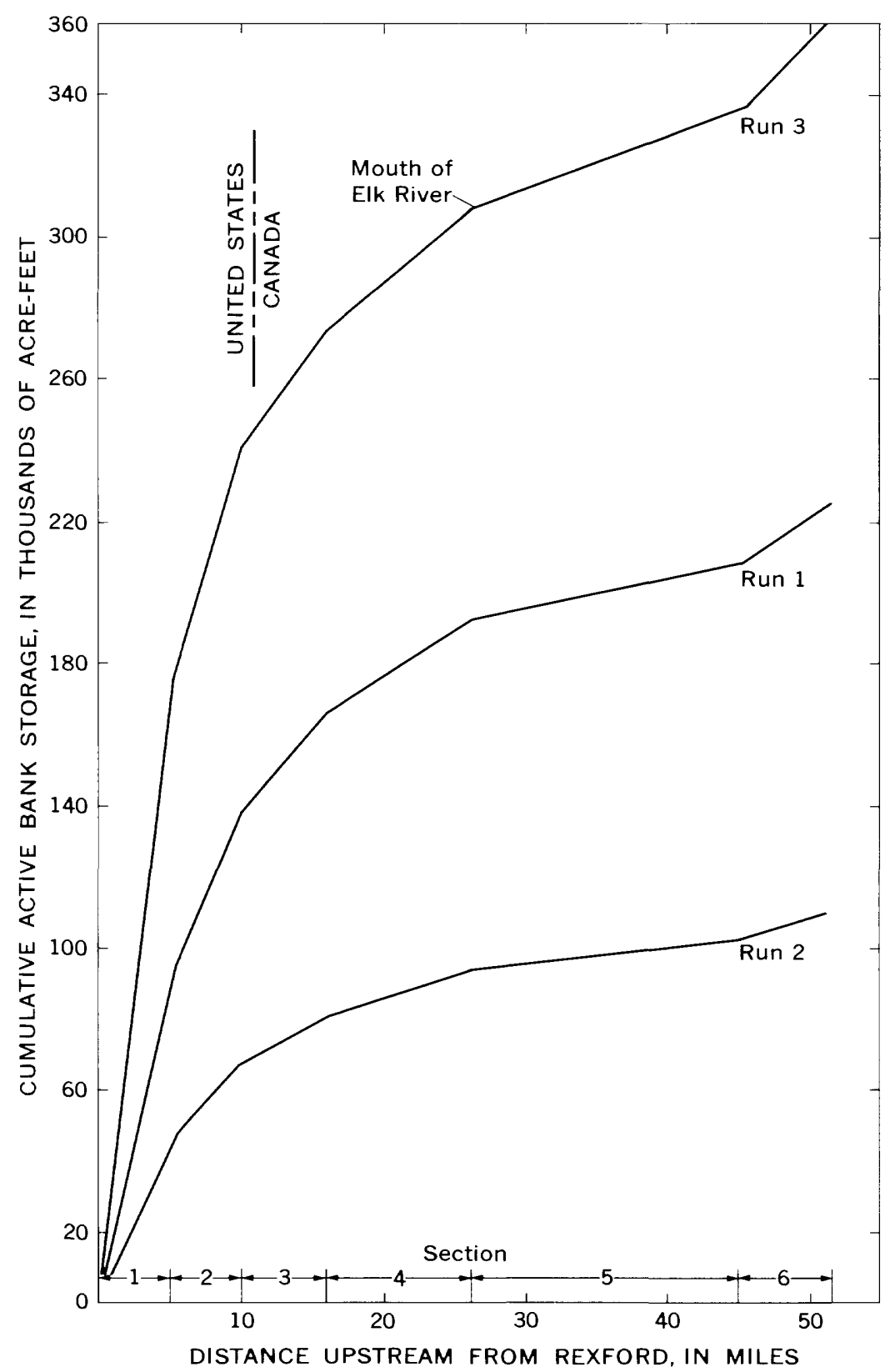

Figure 7.-Cumulative active bank storage above Rexford. 
Various reservoir hydrographs or series of unequal reservoir hydrographs could easily be programmed into the model. Because the reservoir does not yet contain water, any combination of stage hydrographs would be speculative, and a complicated series of reservoir hydrographs might tend only to mask the effect of other parameters. A more sophisticated model should be programmed by a stage hydrograph computed from historic inflows and output from models developed by the U.S. Army Corps of Engineers and Bonneville Power Administration to test reservoir operation.

\section{LIMITS OF THE AREA OF INTENSIVE DATA COLLECTION}

To develop a plan to collect data necessary to estimate bank storage, it is desirable to define the accuracy needed for the estimate. Active reservoir storage is about 5 million acre-feet, and it seems illogical to try to estimate bank storage closer than about 1 percent of active reservoir storage because of possible errors in measuring active reservoir storage. Active bank storage could probably be estimated closer than plus or minus 50,000 acre-feet, but relative to active reservoir storage, further refinement of the bank storage estimate would seem unnecessary. The data-collection program should not be designed to collect data intensively in areas that supply marginal amounts of bank storage.

The largest area along the reservoir where data should be collected intensively to estimate bank storage is between Rexford and the mouth of the Elk River, 28 miles upstream from Rexford, because this is the area of greatest potential bank storage. The area of intensive investigation might be reduced further by considering the limiting value of 50,000 acre-feet. Because the limiting value is a volume of water which depends on $T$ and $S, T$ and $S$ must be known to define conclusively the area of intensive data collection. For planning purposes, however, $T$ and $S$ can probably be estimated close enough to define the limits of the area of intensive data collection. To illustrate the use of the limiting value, suppose that preliminary data were available (laboratory permeabilities or a pump test) to give an idea of $T$ and $S$. If the data suggest that values assumed for $T$ and $S$ in run 1 are reasonable, then active bank storage is estimated as 224,000 acre-feet. The accuracy desired for the final estimate is 50,000 acre-feet, so that subtracting this amount for the estimate leaves 174,000 acre-feet, which could be used in planning reservoir management. This amount of bank storage is distributed within the 20 miles upstream from Rexford (fig. 7). Thus, the area of intensive data collection should be limited to this 20 -mile reach. Of course, the 
final estimate of bank storage would be based on a model of the entire reservoir area. The point is that most of the water in bank storage will be from this 20 -mile reach, where the most time and money should therefore be spent in data collection. Less sophisticated data over the rest of the area will not introduce a serious error in the final estimate. If preliminary data showed $S$ and $T$ values assumed during run 1 to be greatly in error, another proposed area would be defined by analyzing curves from another run.

Defining the limits of the area of intensive data collection east and west of the reservoir is less exact than defining the limit along the length of the reservoir. Obviously, hydrologic data should be collected only from the permeable deposits on the floor of the Rocky Mountain Trench, which is 5-10 miles wide. As annual water-level fluctuations more than 2 miles from the reservoir are estimated as less than 10 feet and appear to be 1-2 feet, the intensive area could probably be limited to about 2 miles from the reservoir without causing serious errors. If, however, inactive bank storage is of interest, almost the entire width of the trench would require data collection because the reservoir will eventually cause a net rise at some places of as much as 80 feet.

The Corps of Engineers' estimate of active bank storage (table 2 ) in the alluvium that will be covered by the reservoir indicates that 10,000 acre-feet would be above the mouth of the Elk River. Regardless of where data are intensively collected on the floor of the trench, the alluvium should be studied intensively to the Elk River because each unit volume of alluvium stores and transmits relatively large volumes of water. Upstream from the Elk River, data could be collected less intensively but still in sufficient quantity to detect major changes in $T$ and $S$.

Conclusions summarized below regarding the size of the area of intensive data collection assume the conceptual model and $T$ and $S$ values for run 1 to be correct. Other values of $T$ and $S$ would define a different area for intensive data collection if the values for run 1 are found to be in error.

1. The area of intensive data collection is determined by the accuracy of measuring active reservoir storage, the magnitude and frequency of the reservoir fluctuation, the slope of the floor of the reservoir, and $T$ and $S$ of the aquifer.

2. The area should extend 20 miles upstream from Rexford.

3. The area should be confined to the floor of the Rocky Mountain Trench within 2 miles of the reservoir.

4. The alluvium along the Kootenai River should be studied most 
intensively between Rexford and the Elk River and in less detail to the head of the reservoir.

\section{DISCUSSION}

This paper is essentially an effort to develop the most economical plan for collecting data to solve, with reasonable accuracy, a specific problem. The principle advantage of the exercise is that known facts are organized and areas where more information will be the most useful are pointed out. Studying the analog results and the mathematical model of Cooper and Rorabaugh helps to relate to one another the physical parameters that affect bank storage. Such an insight helps to evaluate the shortcomings of various approaches and to see the relative importance of various parameters; it is the beginning of a logical data-collection program. The approach also provides people in management with data that allows them to compare this project with other projects with respect to the possible return from allocated funds.

The principal disadvantage of building an electric analog from scanty field data is that the conceptual model generated by the hydrologist may require modification. The analog is essentially an electrical copy of the conceptual model. Without adequate data for checking the analog results, it is difficult to check the concepts used to build it.

At Libby Reservoir, where the conceptual model is based on the surface geology, the question is how deep surface geological concepts can be extended into the subsurface. The surface and subsurface are surely dissimilar, but it is not known to what degree or whether the degree of dissimilarity will cause significant hydrologic differences. Test drilling is necessary to determine the degree of dissimilarity. The problem of checking the validity of the geologic and hydrologic concepts would exist regardless of the type of model used to estimate bank storage. It might be easier to change other models, but without additional field data changes would be meaningless.

The results of the analog allow consideration of several alternatives for studies to estimate better the ground-water gains and losses to the reservoir. The first alternative is simply no further study of the reservoir-aquifer system. Water contributed to the reservoir from the aquifers will be of benefit regardless of whether it is studied or not. Optimum reservoir management, however, requires that the amount of water available to the reservoir be known in advance so that power can be sold on a firm basis and flood-control benefits can be fully realized. For proper management of the reservoir, the amount of water available and 
its worth need to be known. This study points out that a significant amount of water may be associated with bank storage and that it may be worth studying.

A second alternative is to study ground water associated with the reservoir by an approach similar to the one used for estimates made during this study. The cost of a hydrologic study to estimate accurately ground-water storage changes associated with the reservoir would probably be about $\$ 120,000$, based on 1969 costs, and it might cost $\$ 50,000$ per year for 5-10 years to collect and analyze hydrologic data to substantiate and refine the estimate. The total cost for the program would probably be about $\$ 600,000$, based on 1969 costs. If the average yearly bankstorage contribution to the reservoir is 224,000 acre-feet predicted by the analog during run 1 plus 66,000 acre-feet estimated to be stored in the alluvium that will be covered by the reservoir, the total $(290,000$ acre-ft) is about 5.8 percent of active reservoir storage.

This analog approach also indicates that inactive bank storage will remove some water permanently from the Columbia River System; such a removal would be a liability to the powergenerating capacity of the system. Much of the water that goes into inactive bank storage, however, will do so during the spring runoff period and will benefit the flood-control aspects of the Columbia River projects.

A third alternative would be to wait until the reservoir fills and to study bank storage by a water-budget approach. This would involve accurate measurements of inflow and outflow and, if continued for $\mathbf{5}$ or 10 years, might cost more than the second alternative. The results by this procedure have an undefined but large area of uncertainty because of inability to measure within close limits. For periods much less than a year, it is difficult to close the water budget for a reservoir imposed on a natural flow system, because the natural system causes delays between the measurement of aquifer recharge and flow of the recharge into the reservoir.

It is interesting, although academic, to compare the cost of two approaches toward the problem of collecting the geohydrologic data necessary to evaluate bank storage with reasonable confidence. The first approach was made after a brief reconnaissance of the area above Rexford and simply requires test drilling on an arbitrarily selected grid. The second approach was to construct the analog model and to use the results of the model to develop a plan to collect the data in the most critical areas. 
The first approach would cost about $\$ 250,000$ or nearly twice as much as the second, which considers the natural flow system and its contributions to the reservoir in more detail. If the second approach is used, the savings would not be real because it is unlikely that the first would have been completely funded. The second approach may not be completely funded; however, reductions in funding will cause a minimum loss of estimate accuracy because the results of the analog may be used to plan further reductions in collecting data.

The analog approach shows some promise as a technique to estimate bank storage. The approach tends to minimize data collection as well as provide a working model of the reservoiraquifer system. The final working model, whether it is an electric analog or some other kind, would be modified, and predictions would improve as data from a monitoring program became available to check predictions and make corrections. The monitoring program would consist mainly of measurements of streamflow and ground-water levels.

For proper management of the reservoir, the amount of water available from bank storage and from the natural flow system needs to be known in advance. Insofar as reservoir operation and precipitation can be predicted, the model could rapidly calculate the amount of water available from the aquifers. New calculations could be made as unexpected events occur, and thus the model calculations should be dependable for a few months in advance, but less dependable for periods of 6 months or a year. With the aid of a sophisticated model, it may become possible to regulate the reservoir so as to take maximum advantage of water available from the aquifers.

\section{SHORTCOMINGS OF THE ANALOG}

Assumptions used in constructing the electric analog are discussed below to show how they affect the estimate of bank storage. The first sentence in each of the following six sections states the assumption, and the following sentences describe the effect of the assumption on the estimate of bank storage.

1. The reservoir is in full hydraulic connection with the aquifer. Shortly after the reservoir begins to fill, an accumulating clay and silt layer as well as entrapped air will tend to decrease the hydraulic connection. The connection will become worse as clay and silt accumulate and cause bank storage to be less than predicted; the prediction will be come more in error with time.

2. Transmissivity and the storage coefficient do not change with time. As the reservoir fluctuates, the saturated thickness of the 
banks will change from zero to as much as 172 feet. The assumed values of $T$ consider that the banks are always saturated to the maximum flow line of the reservoir. Actually, this would be true during only about 2 or 3 months during an average year. The assumption will cause bank storage to be less than predicted.

3. There is no bank storage in the aquifer beneath the reservoir. The alluvium along the Kootenai River is mostly gravel and appears capable of storing and transmitting large quantities of water per unit volume. The water stored by the alluvium is not considered in the analog, but this water may be accounted for by adding the active bank storage estimated from the volume of alluvium.

4. The reservoir fluctuates $\mathbf{1 7 0}$ feet each year, and the stage hydrograph is identical for 40 years. The maximum fluctuation planned for the reservoir is 172 feet during critical water conditions. The average operating fluctuation probably will be less than $\mathbf{1 7 0}$ feet and will depend on inflow to the reservoir and on reservoir operation. Firm operating rules are being developed for the reservoir but are not yet (1969) completed. Because bank storage is directly dependent upon the annual reservoir fluctuation, assuming a maximum fluctuation will tend to make bank storage a maximum.

5. There is no evaporation or transpiration from the aquifer. This assumption is probably nearly correct. Assuming a maximum 80 -foot rise of water level in the aquifer, the depth to water beneath the floor of the trench will be generally greater than 20 feet. The bank slope above reservoir level is steep, and only in a narrow zone along the edges of the reservoir will the water table be near land surface; thus, the area of relatively high evapotranspiration will be small. During the winter and spring when the reservoir is lowest, snow will cover the exposed floor and retard evaporation.

6. The aquifer receives no recharge from precipitation. This assumption is necessary because field data are insufficient to define the natural flow system into which Libby Reservoir will be introduced. A more sophisticated analysis would require consideration of recharge, which considerably complicates the problem. Bank storage is defined as water entering the aquifer from the reservoir; however, storage increases in the aquifer result from both bank storage and additions by the natural flow system, which receives its water from recharge. As the reservoir stage lowers, water flowing into the reservoir from the aquifer 
may originate from both bank storage and the natural flow system. The total contribution of water to the reservoir from the aquifer is not considered in the electric analog because the analog considers only the bank-storage component. The natural flow system could affect the amount of bank storage, because if water levels in the aquifer near the reservoir are higher than the reservoir during rising stages, bank storage would be small; yet, if the stage of the reservoir lowers faster than groundwater levels, ground water will flow into the reservoir and contribute to its available storage as does bank storage.

Limited field data from the Tobacco Plains indicate that ground-water levels near the east edge of the proposed reservoir rise rapidly in the last part of July or first part of August and slowly decline during the rest of the year. Superimposing the assumed reservoir-stage hydrograph on hydrographs from the natural flow system suggests that water would flow into the aquifers during rising reservoir stages; such a flow would delay the natural ground-water discharge to the Kootenai River until the reservoir stage began to decline in September or October. Thus, the natural flow system may cause bank storage to be smaller than that predicted by the electric analog, but the total ground-water contribution to the reservoir from the aquifer may be larger than predicted bank storage.

\section{PLANS FOR A NEW MODEL}

Construction and manipulation of the analog and discussion of its assumptions help to define plans for a new model to estimate bank storage more accurately. Criteria for a new model determine what field data need to be collected. The analog has helped to define the area necessary for intensive data collection as a function of transmissivity and storage coefficient. Discussion of the results points out that recharge is important and must be considered in the next model. Test drilling and hydrologic testing in the area of intensive data collection, as well as better definition of the natural flow system, would justify construction of a new model. Because the time distribution of bank storage will be important to reservoir operation, the new model would have a much expanded time scale, so that seasonal bank storage could be predicted. The model would include the following modifications of the first model:

1. The hydraulic diffusivity would be based on observed values of $T$ and $S$ for individual areas.

2. Hydraulic connection between the reservoir and aquifer would be modeled as less than 100 percent and as a function of time. 
3. Transmissivity close to the reservoir would be allowed to vary as a function of the reservoir stage.

4. Recharge would be programmed into the model.

5. The alluvium beneath the reservoir would be modeled.

6. The reservoir fluctuation would be based on streamflow record and on reservoir operating-rule curves.

\section{REFERENCES CITED}

Cooper, H. H., Jr., and Rorabaugh, M. I., 1963, Ground-water movements and bank storage due to flood stages in surface streams: U.S. Geol. Survey Water-Supply Paper 1536-J, p. 343-366.

Ferris, J. G., 1950, A quantitative method for determining ground-water characteristics for drainage design: Agr. Eng., v. 31, no. 6, p. 285-291.

Jacob, C. E., 1950, Flow of ground water, Chap. 5 in Rouse, Hunter, ed., Engineering hydraulics: New York, John Wiley \& Sons, p. 321-386. 